\title{
Waste biorefinery towards a sustainable circular bioeconomy: a solution to global issues
}

\author{
Hui Yi Leong ${ }^{1 \dagger}$, Chih-Kai Chang ${ }^{2 \dagger}$, Kuan Shiong Khoo ${ }^{3}$, Kit Wayne Chew ${ }^{4}$, Shir Reen Chia ${ }^{3}$, Jun Wei Lim', \\ Jo-Shu Chang ${ }^{6,7,8}$ and Pau Loke Show ${ }^{3^{*}}$ (D)
}

\begin{abstract}
Global issues such as environmental problems and food security are currently of concern to all of us. Circular bioeconomy is a promising approach towards resolving these global issues. The production of bioenergy and biomaterials can sustain the energy-environment nexus as well as substitute the devoid of petroleum as the production feedstock, thereby contributing to a cleaner and low carbon environment. In addition, assimilation of waste into bioprocesses for the production of useful products and metabolites lead towards a sustainable circular bioeconomy. This review aims to highlight the waste biorefinery as a sustainable bio-based circular economy, and, therefore, promoting a greener environment. Several case studies on the bioprocesses utilising waste for biopolymers and bio-lipids production as well as bioprocesses incorporated with wastewater treatment are well discussed. The strategy of waste biorefinery integrated with circular bioeconomy in the perspectives of unravelling the global issues can help to tackle carbon management and greenhouse gas emissions. A waste biorefinery-circular bioeconomy strategy represents a low carbon economy by reducing greenhouse gases footprint, and holds great prospects for a sustainable and greener world.
\end{abstract}

Keywords: Bio-lipids, Biopolymers, Circular bioeconomy, Waste biorefinery, Wastewater bioremediation

\section{Background}

According to the Worldometer, the current world population records 7.8 billion people as of August 2020, and it is projected to be 10 billion people in 2057 [1]. The high annuals of world population growth are tackling pressing challenges on global issues pertaining to environmental problems and food security which affect the Sustainable Development Goals (SDGs). Particularly, such environmental concerns like pollutions, climate change, global warming, waste disposal and natural resource reduction

\footnotetext{
*Correspondence: showpauloke@gmail.com; PauLoke.Show@nottingham. edu.my

${ }^{\dagger}$ Hui Yi Leong and Chih-Kai Chang contributed equally to this work and should be considered as co-first authors

${ }^{3}$ Department of Chemical and Environmental Engineering, Faculty of Science and Engineering, University of Nottingham Malaysia, Jalan Broga, 43500 Semenyih, Selangor Darul Ehsan, Malaysia

Full list of author information is available at the end of the article
}

have increased at an alarming rate, and these concerns are mostly a consequence of uncontrolled detrimental activities by human being on our Mother Earth [2]. For example, the extensive exploitation of petroleum or fossil fuel resources to produce energy, chemicals and synthetic materials not only causes the depletion of natural non-renewable resources but also impact the high releases of greenhouse gases (GHGs) emission, which affects the environment dramatically [3]. In consequence, these global problems need an imperative solution where circular bioeconomy can play the major role in which a low carbon economy will definitely help to resolve these issues, especially on the climate change through limiting global warming by $1.5^{\circ} \mathrm{C}$ henceforth [4-7].

The term circular bioeconomy, also known as biobased circular economy, is an integrated concept of circular economy and bioeconomy. In other words, it denotes the cascading use of biomass from biological resources

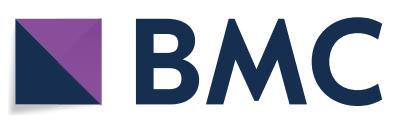

(c) The Author(s) 2021. This article is licensed under a Creative Commons Attribution 4.0 International License, which permits use, sharing, adaptation, distribution and reproduction in any medium or format, as long as you give appropriate credit to the original author(s) and the source, provide a link to the Creative Commons licence, and indicate if changes were made. The images or other third party material in this article are included in the article's Creative Commons licence, unless indicated otherwise in a credit line to the material. If material is not included in the article's Creative Commons licence and your intended use is not permitted by statutory regulation or exceeds the permitted use, you will need to obtain permission directly from the copyright holder. To view a copy of this licence, visit http://creativeco mmons.org/licenses/by/4.0/. The Creative Commons Public Domain Dedication waiver (http://creativecommons.org/publicdomain/ zero/1.0/) applies to the data made available in this article, unless otherwise stated in a credit line to the data. 
into a systemic approach for economic development. A circular bioeconomy offers an efficient utilisation of biomass which include wastes and side streams for the sustainable production of high value-added products (e.g., food, biomaterials, feed and bioenergy). The benefits of circular bioeconomy includes: (1) improved resource and eco-efficiency, (2) lower GHGs footprints, (3) reduced reliance of fossil resources and (4) valorisation of side and waste materials from numerous sources such as agroindustrial aquaculture and fishery. This concept focuses on the idea of recycling, reuse, remanufacture and maintaining a sustainable manufacturing process to generate useful bioproducts. Hence, circular bioeconomy can be reflected as a low carbon economy since it exhibits the potential on developing a sustainable and greener environment [7-9].

Biorefining is among one of the most primary facilitating strategies of the bio-based circular economy that closes the loop of fresh or raw resources, water, minerals and carbon. It can be defined as the sustainable bioprocesses that efficiently utilise biomass resources for the production of various marketable products and metabolites (e.g., carbohydrates, proteins, lipids, bioactive compounds and biomaterials) [10]. Furthermore, waste biorefinery receives as much interest or even higher as it represents a decent waste management approach [2, $11,12]$. Bioprocesses utilising waste resources to produce biomaterials and biofuels can greatly elude fossil resources as the production feedstock and this prevents the natural resources from complete depletion. This approach does not only sustains the energy-environment nexus but also protects the environment by mitigating the carbon footprints (i.e., GHGs emission from burning fossil resources) [13]. Moreover, these bioprocesses can be incorporated with other management facilities such as wastewater treatment [14]. Biopolymers (e.g., polyhydroxyalkanoates and polyhydroxybutyrates) and biofuels (e.g., biodiesel, bioethanol, biohydrogen and biogas) are eco-friendly bioproducts that can be produced from various bioprocesses using a wide selection of renewable feedstocks [15]. As for the biofuels production, metabolites like lipids and carbohydrates are first synthesised through bioprocesses which are then followed by further processing on the metabolites into bioenergy. On the other hand, bioprocesses that involves fermentation can directly synthesize biopolymers [e.g., polyhydroxyalkanoates (PHAs)] [8, 16, 17].

Taking the above issues into consideration, this review article aims to evaluate the waste biorefinery advocating toward a circular bioeconomy. Several case studies on the bioprocesses regarding the waste biorefinery to produce biopolymers and bio-lipids have been reviewed. Besides that, the investigation of bioprocesses incorporated with wastewater treatment have been analysed and well discussed. The final section of this review comprehensively evaluated on how the integrated concept of waste biorefinery and circular bioeconomy can contribute towards resolving the global issues especially on the environmental concerns and food security (see Fig. 1). Circular bioeconomy is crucial and possesses vast potential towards a sustainable green world. Respectively, waste biorefinery holds great prospective for the forthcoming circular bioeconomy.

\section{Waste biorefinery promoting a circular bioeconomy}

Petroleum or fossil fuel is a natural resource which has been the utmost important production feedstock for energy (e.g., transportation fuels) and synthetic materials (e.g., plastics and chemicals) for decades. However, they are non-renewable and possess environment-threatening features which causes climate change by the emission of GHGs mainly carbon dioxide $\left(\mathrm{CO}_{2}\right)$ to the atmosphere. These environmental issues have raised the global awareness and there are a great deal of researches on carbon mitigation and adaptation [18]. Shifting towards a waste biorefinery model from a petroleum refinery model indicates a great effort on the carbon management and GHGs mitigation. Waste biorefinery involves in the establishment of a sustainable circular bioeconomy based on the philosophy of recycle, reuse, remanufacture and maintaining by shifting from a linear economy according to the principle of take, make and dispose $[7,19,20]$.

Bioprocesses using waste materials which consists of municipal solid and liquid waste to produce value-added bioproducts and metabolites regarded as waste-to-treasure has received increasing attention as the products produced are renewable and display environmental benign biodegradability characteristics. The bioprocessing of waste biorefinery on the production of biopolymers and bioenergy does not only addresses the energy and environmental security concerns, in fact it signifies a better management of waste streams. It is an eco-friendly and economically sound platform as the production feedstock is sustainable and low in cost [21]. Various kind of waste materials such as food waste [22], side stream from industries (e.g., paper and pulp industry, beer and wine industry, starch and juice industry), agro-industrial byproduct $[23,24]$, forest and agriculture waste, lignocellulosic material [25] as well as wastewater or sludge [26], have been efficiently valorised into useful and marketable bio-based products $[8,20,27]$. Several case studies on the bioprocesses using waste for biopolymers and bio-lipids to be further converted into biofuels production as well as bioprocesses for wastewater treatment are next discussed in the following sub-sections. 


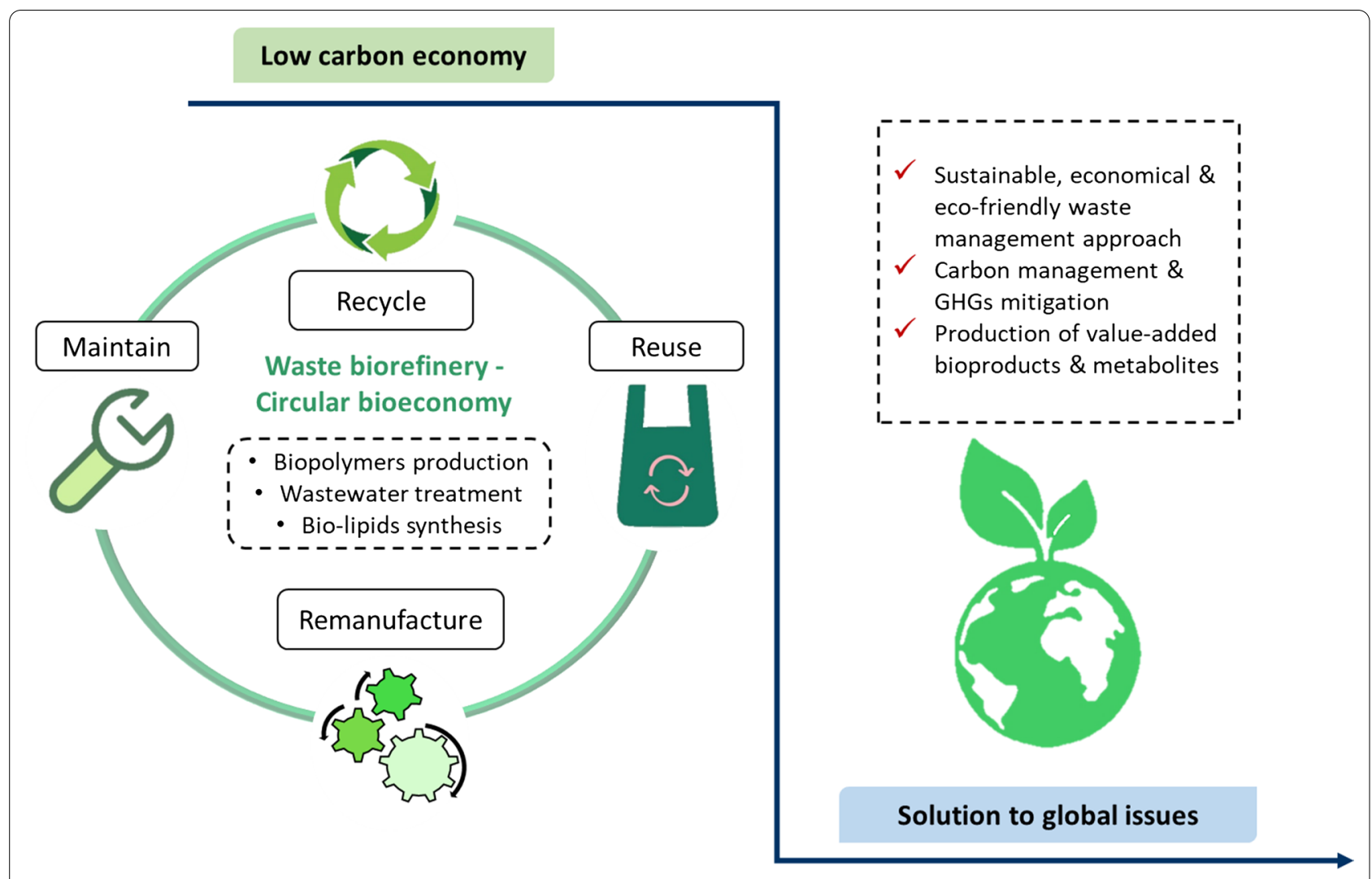

Fig. 1 Schematic view delineates the outline of this review article. The concept of low carbon economy involves recycling, reusing, remanufacturing and maintaining existing processes

\section{Bioprocesses with waste for biopolymers synthesis}

Shifting to a more eco-benign environment, PHAs which represent the green biopolymers have captured tremendous attention from both the industry and scientific community driven by the need to replace conventional petroleum-derived non-degradable polymers or plastics. They possess enormous inherent properties such as insolubility in water, non-toxicity, biodegradability, biocompatibility, piezoelectricity and thermoplasticity, and hence showing potential as substitute of petrochemical plastics (e.g., polypropylene and polystyrene) [28]. PHAs, a type of linear polyesters of hydroxyalkanoates (HAs), can be produced through microbial fermentation with renewable resources like waste and side streams [29, 30]. Usually, they are accumulated as intracellular carbon and energy storage compounds in the culture under limited growth conditions with excess carbon sources. PHAs can be divided into three groups, which are based on the number of carbon atom: SCL-PHAs (short chain length PHAs; 3-5 carbon atoms), MCL-PHAs (medium chain length PHAs; 6-15 carbon atoms) and LCL-PHAs (long chain length PHAs; ' 15 carbon atoms). There are many varieties of PHAs, for instance, poly(3-hydroxybutyrate)
(PHB), poly(3-hydroxyvalerate) (PHV) and poly(3hydroxybutyrate-co-3-hydroxyvalerate) (PHBV). PHAs have excellent potential applications in industrial, agricultural, domestic and medical field. For example, they are widely applied in tissue engineering as supportive scaffolds, in packaging industries and in drug delivery as nanoparticles [31-34].

Reutilisation of waste resources using bioprocesses to produce biomaterials like PHAs gains increasing importance for environmental and socio-economic reasons. This initiative supports an eco-friendly campaign besides reducing the production cost. As an example, the utilisation of $\mathrm{CO}_{2}$ and valeric acid in the Cupriavidus necator DSM 545 fermentation to tailor microbial PHBV. The carbon fixation and utilisation system have been successfully applied to produce the microbial bioplastic, and this will achieve a low carbon economy [30]. Another study by Koller et al. [35] reported that the valorisation of surplus agricultural waste materials into cheap and good carbon, nitrogen and phosphorus sources with a highly osmophilic strain on the production of PHA. These materials included the hydrolysation of whey permeate and glycerol liquid phase as carbon source, as well as 
meat and bone meal as nitrogen and phosphorus sources. These hydrolysed waste resources utilised in the fermentation process can reduce the production cost of PHA. Besides that, the assimilation of agro-industrial oily waste with Pseudomonas aeruginosa 42A2 (NCIB 40045) fermentation for PHA production was studied by Fernández et al. [36]. Waste frying oil and waste-free fatty acids from soybean oil were used as the carbon source on the microbial fermentation, and successfully accumulated PHA of $29.4 \%$ and $66.1 \%$, respectively.

Other than that, $\mathrm{Yu}$ and team studied the PHAs production using starchy wastewater with Alcaligenes eutrophus (ATCC17699) cultivation [37]. The research employed a two-step process of microbial acidogenesis and acid polymerisation. The organic waste firstly undergoes acidogenesis to produce volatile fatty acids (VFAs) (e.g., acetic, propionic, and butyric acid) under anaerobic conditions, and was subsequently used to produce microbial PHAs. Also, dairy industrial waste, rice bran and sea water were employed by RamKumar Pandian et al. to synthesise PHB with Bacillus megaterium SRKP-3 fermentation. The maximum PHB concentration $(11.32 \mathrm{~g} / \mathrm{L})$ was achieved in the microbial culture with the dairy waste [38]. Furthermore, the utilisation of food waste, acidogenic effluents and waste glycerol for the production of PHAs were reported previously by Venkateswar Reddy and Venkata Mohan [39] and Cavalheiro et al. [40], respectively. The former study showed that the microbial culture with acidogenic effluents (fermented food waste) accumulated a higher PHA (39.6\%) compared to that of with unfermented food waste (35.6\%). The study demonstrated the production of biohydrogen along with biopolymer using microbial fermentation process with fermented food waste. Whereas, the latter study valorised waste of crude glycerol by-product of biodiesel production with Cupriavidus necator DSM 545 fermentation to produce PHB (50\% of PHB, w/w). To date, there are still many ongoing researches on the biopolymers production by valorisation waste streams with bioprocesses [41-44].

Bacterial cellulose (BC) is an alternative green biopolymer which has also been extensively studied by the scientific community. $\mathrm{BC}$ is a natural nano-polymer that displays numerous interesting characteristics, including higher degree of polymerisation, higher tensile capability, higher crystallinity, higher purity as well as good water absorbing and holding capacity, in addition to the good biological adaptability $[45,46]$. These inherent properties have prompted the wide applications of $\mathrm{BC}$ in various fields include pharmaceutical, biomedical and food [47]. Many researchers have valorised different type of wastes with bacterial cultivation to produce $\mathrm{BC}$, for instance, waste fibre sludge [48], waste from beer industry [49], black strap and brewery molasses [50], wastewater of candied jujube-processing industry [51], corn steep liquor [52], sweet lime pulp waste [53] and many more [47]. Lin et al. [49] studied the cultivation of Gluconacetobacter hansenii CGMCC 3917 with only waste beer yeast as the nutrient and carbon sources for synthesis of $\mathrm{BC}$, and a promising result was obtained. The bacterial culture achieved from the optimised waste beer yeast hydrolysate (treated by a two-step pre-treatment that incorporated ultrasonication and mild acid hydrolysis as well as optimisation of sugar concentration) resulted in a higher $\mathrm{BC}$ yield and demonstrated good physicochemical features (i.e., holding capacity, release rate and absorption rate of water) compared to that of using untreated waste beer yeast and conventional chemical media. Table 1 shows the various bioprocesses utilising waste materials for the biopolymers synthesis.

\section{Bioprocesses with waste for bio-lipids synthesis}

The bioprocessing of waste contributes to both the production of green biopolymers and accumulation of bio-lipids. Production of microbial lipids using lowcost substrates from waste materials has attained much attention from both the industry and research areas as the alternative feedstock for biofuels production, health food supplements and oleo-chemical industries. Oleaginous microorganisms such as yeasts, cyanobacteria, algae, some bacteria, and fungi can accumulate significant amount of lipids of their body weight ( 20-80\%) [54]. The microbial oils are safe-to-use, non-toxic and biodegradable, whereby their industrial applications do not depend on petroleum-based chemicals. These features sustenance a greener environment for the society, and can help to alleviate several global issues [23, 55-59]. Nowadays, many researchers focused on the bioprocesses utilising waste materials for microbial lipids production [60, 61]. For instance, Fontanille et al. [56] reported the feasibility of simultaneous bio-valorisation of VFAs (e.g., acetic, propionic and butyric acid) and glycerol as the carbon sources for oleaginous yeast Yarrowia lipolytica MUCL 28849 culture to generate microbial lipids. These carbon sources are inexpensive and can be easily obtained from industries as by-product or waste. Similarly, Gong et al. studied the conversion of acetic acid waste into microbial lipids by cultivating Cryptococcus curvatus ATCC 20509 under various culture modes, and promising yeast-derived lipids yields were attained [62].

In addition, Huang et al. [63] and Xavier et al. [64] studied the valorised acetic acid and hemicellulose hydrolysate, respectively, on the production of yeastderived lipids. The former study utilised $4-20 \mathrm{~g} / \mathrm{L}$ acetic acid as the sole carbon source with Rhodosporidium toruloides AS 2.1389 culture to synthesise lipids of approximately $38.6-48.2 \%$, while the latter study 
Leong et al. Biotechnol Biofuels $\quad$ (2021) 14:87

Page 5 of 15

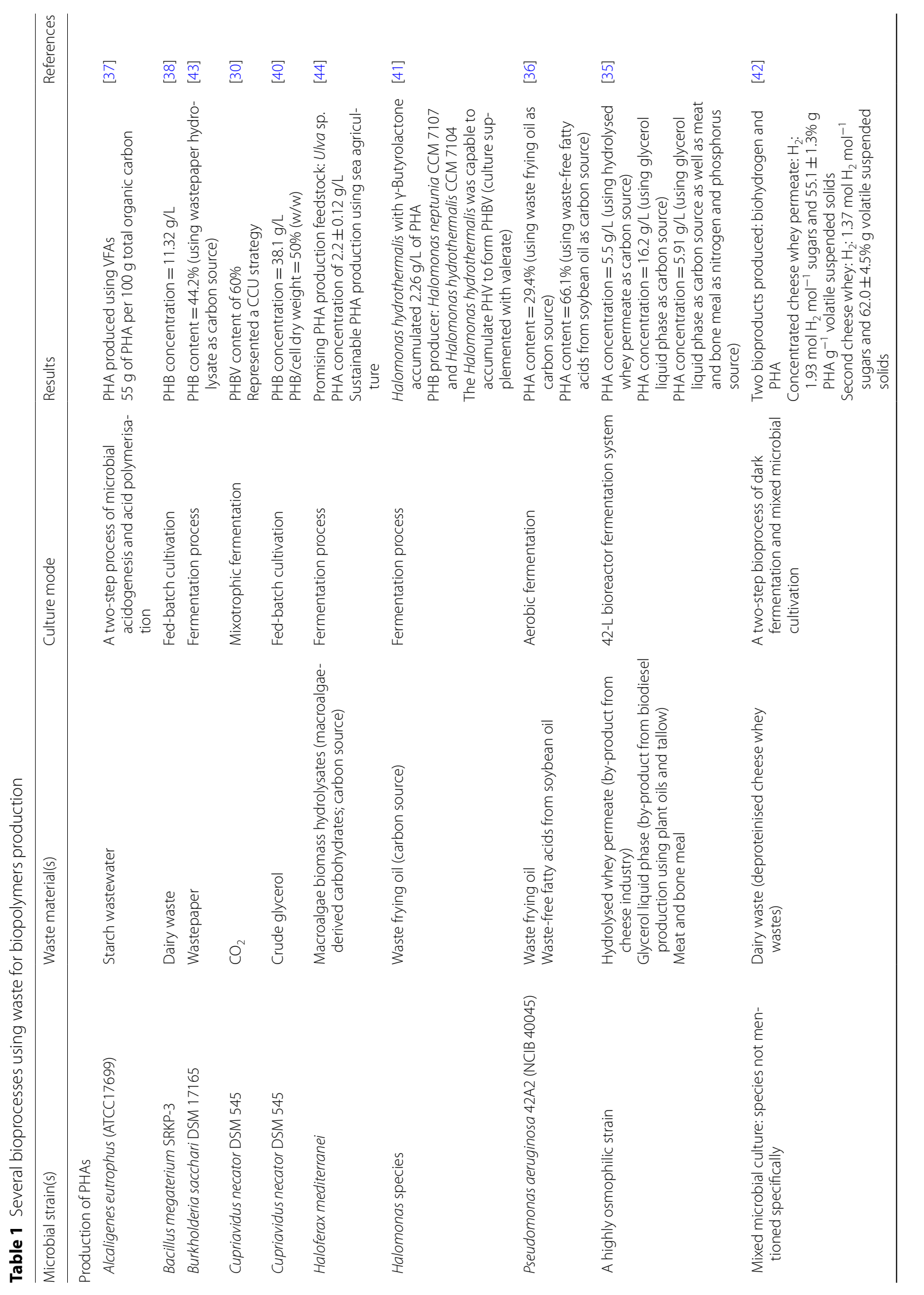




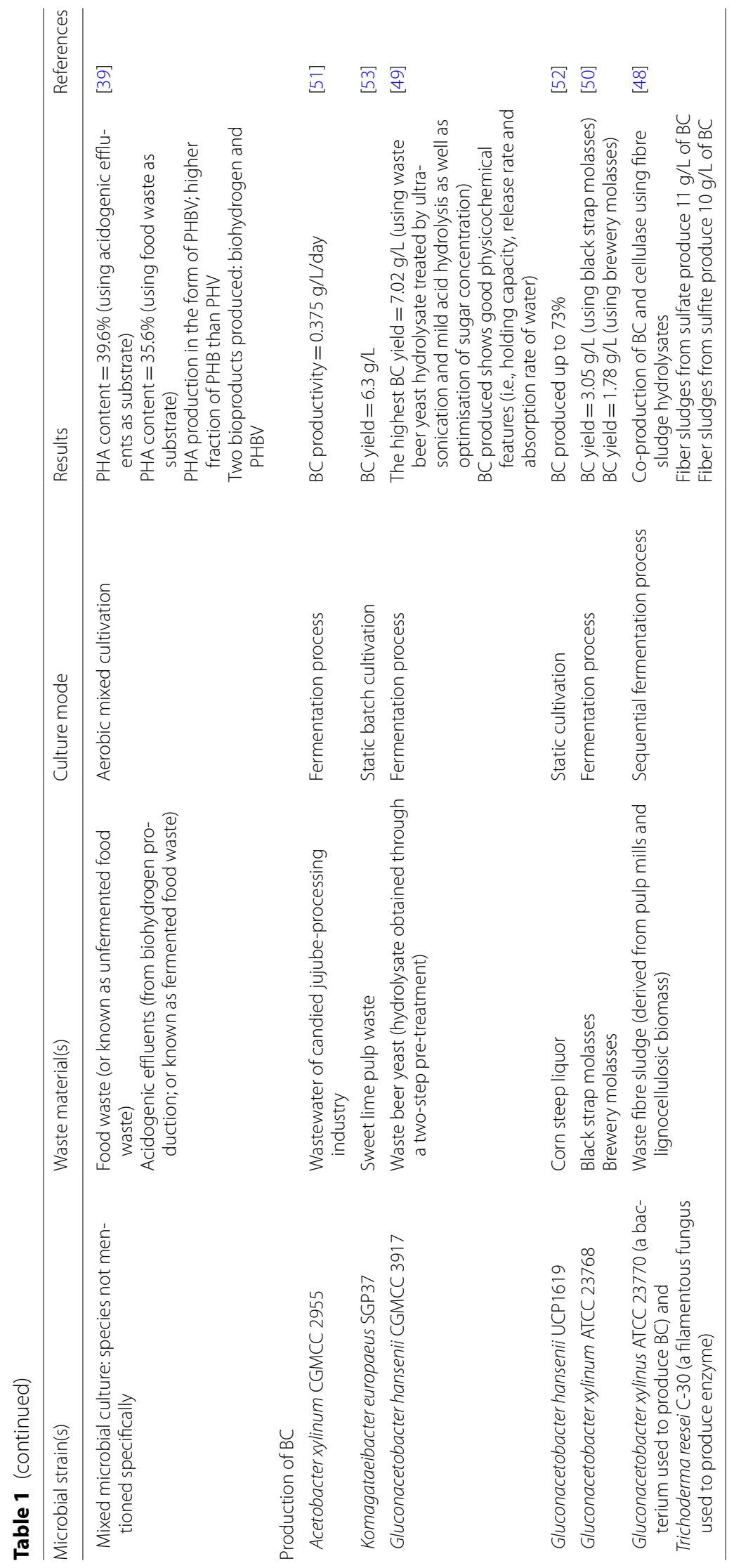


employed hemicellulose hydrolysate from sugarcane bagasse to cultivate Lipomyces starkeyi DSM 70296, and lipid content of $26.1-26.9 \%$ was obtained. Besides, Lopes et al. [65] reported the production of microbial lipids and some useful metabolites such as citric acid and lipase through cultivation of Yarrowia lipolytica W29 (ATCC 20460) with pork lard. Pork lard is an animal fat which is rarely used in food preparation, as its consumption causes vascular and heart diseases, and hence it is normally regarded as waste. This study revealed the possible usage of waste from meat processing industries for microbial oils synthesis.

Microalgae oil has gained high popularity in industrial applications such as biodiesel and health food supplements [66, 67]. Microalgal-derived biodiesel has excellent properties like low viscosity and represents as a carbonneutral renewable fuel which benefits the environment and should be used to replace fossil fuels. Moreover, microalgae oil also contains polyunsaturated fatty acids (PUFAs) which can be further processed into health food supplements $[68,69]$. Valorisation of waste into microalgae bioprocessing represents a greener and cost-effective circular bioeconomy approach. In this regard, Hong et al. [70] suggested that the empty palm fruit bunches can be a potential source for the production of microalgal lipids that contain significant amount of docosahexaenoic acid (DHA). DHA (C22:6n - 3) is an omega-3 PUFA that plays a vital role in brain and eye development. Another study by Chiranjeevi and Venkata Mohan [71] reported an integrated process of acidogenic fermentation and microalgae culture using wastewater to produce lipids. Two types of fermented effluents, include fermented distillery wastewater and fermented dairy wastewater, were employed in the cultivation with different culture modes (i.e., fermented distillery wastewater: mixotrophic culture and fermented dairy wastewater: both hetero- and mixotrophic culture).

Furthermore, microalgae Chlorella vulgaris FACHB-31 cultured with landfill leachate in membrane photobioreactors to produce bio-lipids was reported by Chang et al. [72]. The bio-lipids produced exhibited good combustion properties by owning low linolenic acid content (8.32\%) and high cetane number $(60.96 \%)$. A study by Nguyen et al. [73] also reported the utilisation of wastewater in the microalgae cultivation for lipids production. Seafood wastewater effluent was used to culture Chlorella vulgaris SAG 211-19, and lipid content of $32.15 \%$ was successfully produced. Much research efforts are being placed to valorise waste on microalgae cultivation to generate useful bioproducts [74-79]. Table 2 shows numerous bioprocesses using waste materials to synthesise microbial lipids. Collectively, assimilation of industrial by-product or waste biorefinery could be a good choice to turn the unwanted substances into useful product such as biopolymers and bio-lipids which represents a sustainable and economical waste management approach.

\section{Bioprocesses for wastewater treatment}

Wastewater or sludge such as sewage, domestic wastewater from households and industrial wastewater are usually generated through agricultural, industrial, domestic and commercial activities. The wastewater contains biological, chemical and physical pollutants, therefore, a proper wastewater treatment process is crucial to minimise the water pollution besides attaining environmental security. Looking towards this perspective, bioprocessing represents a potential wastewater treatment approach. In addition, wastewater reclamation with bioprocessing to produce value-added products is a crucial research field as wastewater contains vast amount of nutrients that is essential to nurture microbial culture (e.g., soluble and insoluble organic compounds which represent rich source of nitrogen, phosphorus and ammonium). The strategy of cultivating microorganisms using wastewater will promote the bioremediation of the wastewater in which reduces the cultivation cost and allows the production of many useful bio-based products (e.g., biopolymers, biofuels and health food supplements) and metabolites (e.g., proteins, lipids, carbohydrates and bioactives) to be co-synthesised [14, 80-82]. Sarris et al. [83] evaluated the cultivation of Saccharomyces cerevisiae MAK-1 with olive mill wastewater treatment. A notable decolourisation and phenol removal efficiency 63\% and $34 \%$, respectively, for the wastewater bioremediation were reported. Besides, the microbial culture enriched with the wastewater showed promising outcomes on the bioethanol and lipids production. Various researches have been conducted in this area, and there are still many ongoing investigations due to the potential of wastewater reclamation using bioprocesses. Various examples of bioprocesses incorporated with wastewater treatment and reclamation are presented in Table 3. Valorisation of waste into bioprocesses on the production of biopolymers and bio-lipids as well as bioprocesses for wastewater bioremediation can be represented as a sustainable and economical approach towards achieving a circular bioeconomy.

\section{Strategies of waste biorefinery-circular bioeconomy towards solving the global issues}

Global issues relating to the environment and food security are the defining problems of our time that have triggered the global awareness of the society. Much efforts have been made by different parties including the government, non-governmental organisations (NGOs), scientific communities and academia to resolve the problems 


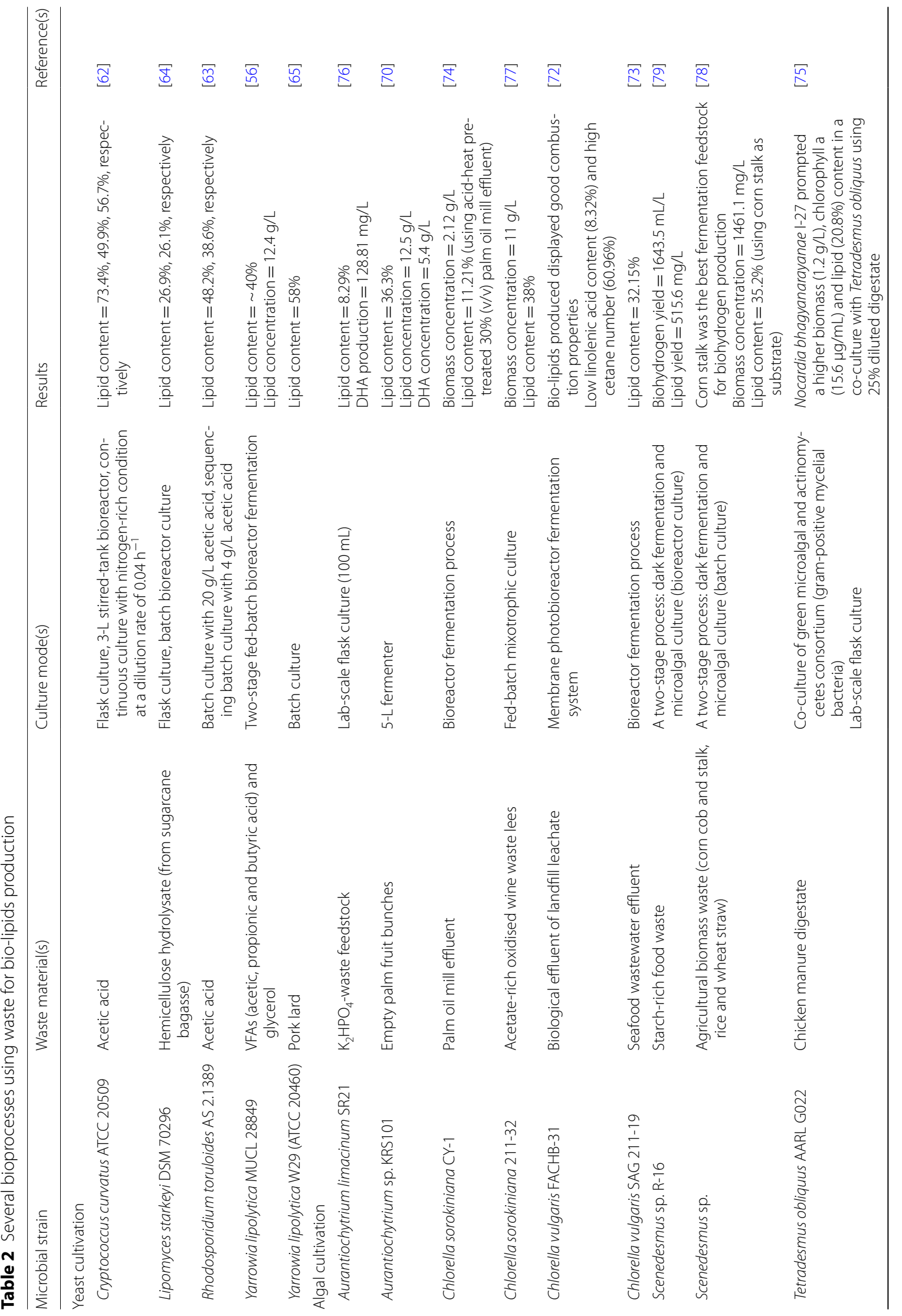




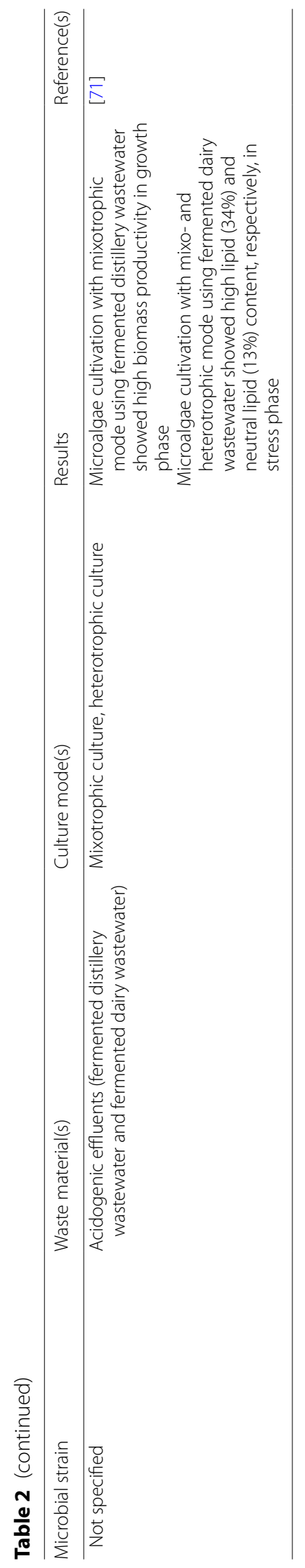


Table 3 Several bioprocesses integrated with wastewater bioremediation

\begin{tabular}{|c|c|c|c|}
\hline Microbial strain & Type of wastewater & Results & Reference(s) \\
\hline Aspergillus oryzae & Potato processing wastewater & $\begin{array}{l}\text { COD removal efficiency }=91 \% \\
\text { Total soluble nitrogen removal effi- } \\
\text { ciency }=98 \% \\
\text { Total soluble phosphorus removal effi- } \\
\text { ciency }=97 \% \\
\text { Lipid concentration }=3.5 \mathrm{~g} / \mathrm{L}\end{array}$ & [84] \\
\hline Bjerkandera adusta MUT 2295 & $\begin{array}{l}\text { Coloured wastewaters: textile industry } \\
\text { wastewater, tannery industry wastewater } \\
\text { and industrial dyes }\end{array}$ & $\begin{array}{l}\text { Bjerkandera adusta MUT } 2295 \text { effectively } \\
\text { degraded and detoxified most of the } \\
\text { coloured wastewaters }\end{array}$ & [85] \\
\hline $\begin{array}{l}\text { Microalgae: Chlorella sorokiniana DBWC2 } \\
\text { and Chlorella sp. DBWC7 } \\
\text { Bacteria: Klebsiella pneumoniae ORWB1 and } \\
\text { Acinetobacter calcoaceticus ORWB3 } \\
\text { (co-culture of microalgae-bacteria consor- } \\
\text { tium) }\end{array}$ & Raw dairy wastewater & $\begin{array}{l}\text { COD removal efficiency }=90.49 \% \\
\text { Nitrate removal efficiency }=84.69 \% \\
\text { Biomass concentration }=2.87 \mathrm{~g} / \mathrm{L}\end{array}$ & {$[86]$} \\
\hline Chlorella vulgaris FACHB-31 & Mixed piggery-brewery wastewater & $\begin{array}{l}\text { Ammonia removal efficiency }=100 \% \\
\text { TN removal efficiency }=96 \% \\
\text { TP removal efficiency }=90 \% \\
\text { COD removal efficiency }=93 \% \\
\text { Biomass concentration }=2.85 \mathrm{~g} / \mathrm{L}\end{array}$ & [87] \\
\hline $\begin{array}{l}\text { Chlorella vulgaris AG } 30007 \text { and Pseu- } \\
\text { domonas putida ATCC } 17514 \text { (co-culture of } \\
\text { microalgae-bacteria consortium) }\end{array}$ & Municipal wastewater & $\begin{array}{l}\text { COD removal efficiency }=86 \% \\
\text { Nitrogen removal efficiency }=78-85 \% \\
\text { Phosphorus removal efficiency }=54-65 \%\end{array}$ & [88] \\
\hline $\begin{array}{l}\text { Chlorella vulgaris NIES-227 } \\
\text { (co-culture of microalgae-bacteria consor- } \\
\text { tium) }\end{array}$ & Sewage (activated sludge) & $\begin{array}{l}\text { COD removal efficiency }=82.7 \% \\
\text { Nitrogen removal efficiency }=75.5 \% \\
\text { TP removal efficiency }=100 \% \\
\text { Biomass productivity }=343.3 \mathrm{mg} / \mathrm{L} / \mathrm{d} \\
\text { The biomass produced showed a higher } \\
\text { calorific value and protein content }\end{array}$ & [89] \\
\hline Micractinium sp. IC-76 & Municipal wastewater & $\begin{array}{l}\text { Nitrogen removal efficiency }=96.4 \% \\
\text { Phosphorus removal efficiency }=77.8 \% \\
\text { Biomass productivity }=37.18 \mathrm{mg} / \mathrm{L} / \mathrm{d} \\
\text { Lipid content }=36.29 \%\end{array}$ & [90] \\
\hline Saccharomyces cerevisiae MAK-1 & Olive mill wastewater & $\begin{array}{l}\text { Remarkable decolourisation }(\sim 63 \%) \text { and } \\
\text { phenol removal efficiency }(\sim 34 \%(\mathrm{w} / \mathrm{w})) \\
\text { Co-production of bioethanol and lipids }\end{array}$ & [83] \\
\hline $\begin{array}{l}\text { Scenedesmus sp. (co-culture of microalgae- } \\
\text { bacteria consortium) }\end{array}$ & Starch wastewater (anaerobic sludge) & $\begin{array}{l}\text { Co-cultivation enhanced biohydrogen } \\
\text { production and performed wastewater } \\
\text { bioremediation } \\
\text { COD removal efficiency }=80.5 \% \\
\text { Total nitrogen (TN) removal effi- } \\
\text { ciency }=88.7 \% \\
\text { Total phosphorus (TP) removal effi- } \\
\text { ciency }=80.1 \% \\
\text { Biohydrogen yield }=1508.3 \mathrm{~mL} / \mathrm{L} \\
\text { Total lipid concentration }=0.36 \mathrm{~g} / \mathrm{L} \\
\text { Energy conversion efficiency }=34.2 \%\end{array}$ & [91] \\
\hline Bacterial consortium 'Bx' & Textile wastewater contains reactive dye & $\begin{array}{l}\text { Maximum decolourisation rates }=88-97 \% \\
\text { Chemical oxygen demand (COD) removal } \\
\text { efficiency }=95-98 \%\end{array}$ & [92] \\
\hline PHA-storing and filamentous bacteria & Municipal wastewater & $\begin{array}{l}\text { COD removal efficiency }=70 \% \\
C_{\text {sol }} \text { concentration removal effi- } \\
\text { Ciency }=60 \% \text { (sol: soluble) } \\
\text { Nitrogen removal efficiency }=24 \% \\
\text { Phosphorus removal efficiency }=46 \% \\
\text { Co-produced PHA }\end{array}$ & [93] \\
\hline
\end{tabular}


Table 3 (continued)

\begin{tabular}{|c|c|c|c|}
\hline Microbial strain & Type of wastewater & Results & Reference(s) \\
\hline Microbial community & $\begin{array}{l}\text { Lactate wastewater (obtained from cattle } \\
\text { slaughterhouse) }\end{array}$ & $\begin{array}{l}\text { COD removal efficiency }=12-30 \% \\
\text { Lactate removal efficiency }=54-99.8 \% \\
\text { Biohydrogen yield }=0.08-0.95 \mathrm{~mol}_{2} / \\
\text { mol lactate uptake (by dark fermentation } \\
\text { process) } \\
\text { Identified microbial = Clostridium, Sporan- } \\
\text { aerobacter and Pseudomonas }\end{array}$ & [94] \\
\hline Sulphate reducing bacteria consortium & $\begin{array}{l}\text { Real wastewater from Okhla industrial area } \\
\text { effluent }\end{array}$ & $\begin{array}{l}\text { Sulphate removal efficiency }=90 \% \\
\text { Chromium removal efficiency }=82.6 \% \\
\text { Cadmium removal efficiency }=86.6 \% \\
\text { Zinc removal efficiency }=54.09 \% \\
\text { Lead removal efficiency }=49.8 \% \\
\text { Nickel removal efficiency }=10.3 \% \\
\text { Oil and grease removal efficiency }=75 \%\end{array}$ & [95] \\
\hline $\begin{array}{l}\text { Not specified (co-culture microbial con- } \\
\text { sortium: microalgae, bacteria and other } \\
\text { microscopic organisms) }\end{array}$ & Domestic sewage & $\begin{array}{l}\text { TN removal efficiency }=72-83 \% \\
\text { TP removal efficiency }=100 \%\end{array}$ & [96] \\
\hline Not specified & Municipal biological wastewater & $\begin{array}{l}\text { COD removal efficiency }=83 \% \\
\text { TN removal efficiency }=80 \% \\
\text { PHA content }=49 \%\end{array}$ & [97] \\
\hline
\end{tabular}

progressively [4-6]. An unprecedented climate change (i.e., ever-changing weather patterns) can threaten the production of food crops which will cause a major setback in food sources. A speedy industrialisation and urbanisation are regarded as the major contributing factors on climate change as these processes release a high and unsafe level of GHGs mostly $\mathrm{CO}_{2}$ emissions to the atmosphere. The burning of fossil fuels is also among the most intimidating actions causing high GHG emissions [98-100]. A special report issued by Intergovernmental Panel on Climate Change (IPCC) in October 2018 stated that a global warming of $1.5{ }^{\circ} \mathrm{C}$ could trigger the negative impacts of climate change in terms of sea level rise and unsecure food production [6]. In this regard, waste biorefinery incorporated with circular bioeconomy represents a low carbon economy by involving $\mathrm{CO}_{2}$ sequestration which can resolve the global issues. Moreover, this strategy also signifies a sustainable and economical manner of waste disposal [7-9].

The valorisation of waste or side streams into bioprocesses for the production of value-added bioproducts such as biopolymers and biofuels could potentially replace the utilisation of fossil fuels as the production feedstock which ensures an ecologically friendly carbon flow. This approach is regarded as a waste-as-a-value, waste-to-wealth or zero-waste plan which would highly contribute as a decent, green, and low-cost waste disposal means. In addition, the bio-based products produced possess environmental benign properties such as non-toxicity, biodegradable and biocompatible that supports an eco-friendly campaign, and hence promoting a greener environment globally. Numerous environmental problems like global warming, water and environment pollution, waste disposal as well as natural resource depletion can then be unravelled. As an example, the development of bioplastics or biopolymers which substantially replace conventional petrochemical plastics can help to minimise plastic pollution that demonstrates adverse impacts in soil and marine ecosystem [101, 102]. Other than that, a great deal of research attention has been placed on improving the efficiency, effectiveness, and economic feasibility of wastewater treatment, and, therefore, water pollution can be conceivably addressed. The bioprocesses integrated with wastewater treatment (i.e., a type of biological wastewater treatment) have been proved to effectively bioremediate wastewater (e.g., sewage and industrial wastewater e). Besides that, wastewater reclamation for value-added bio-based products can be achieved by cultivating live microorganisms such as bacteria, algae and yeasts with wastewater [103]. To attain an energy security, bioenergy and biofuels has been produced from the microorganisms, and its production is non-dependent on petroleum feedstock. GHGs' mitigation and carbon management can be achieved using biofuels for various purposes (e.g., transportation fuels). An economical manner of biofuels production (or microbial lipids synthesis) can then be accomplished by bioprocessing with a waste biorefinery [69, 104, 105].

Collectively, a waste biorefinery-circular bioeconomy strategy could ensure an energy-environmental security. Having an environmental security prompts a food security for the globe. Food security is of extremely importance to ensure an adequate supply of food resources for the increasing world population, and thus to avoid world 
hunger issue. Also, the quality of life and human health can be maintained through an environmental-food security. Hence the efforts of a circular bioeconomy will help to regenerate the good efficiency and prosperity in a lifelong cycle without worry of the economic impacts of environmental, food and energy.

\section{Conclusions}

A sustainable and eco-benign manner of waste disposal is critical to protect the environment and human health. In this regard, waste biorefinery exemplifies its potential. Valorisation of waste or side streams into bioprocessing to produce value-added bioproducts like biopolymers and bio-lipids remarkably advocate a sustainable circular bioeconomy. A circular bioeconomy which represents a low carbon economy by reducing GHGs footprint helps to resolve the global issues significantly such as environmental problems and food security. A waste biorefinery-circular bioeconomy strategy, therefore, holds great prospective for a sustainable green world and should be prompted.

\begin{abstract}
Abbreviations
BC: Bacterial cellulose; COD: Chemical oxygen demand; DHA: Docosahexaenoic acid; GHG: Greenhouse gas; HA: Hydroxyalkanoate; IPCC: Intergovernmental panel on climate change; LCL: Long chain length; MCL: Medium chain length; NGO: Non-governmental organisation; PHA: Polyhydroxyalkanoate; PHB: Poly(3-hydroxybutyrate); PHBV: Poly(3-hydroxybutyrate-co-3-hydroxyvalerate); PHV: Poly(3-hydroxyvalerate); PUFA: Polyunsaturated fatty acid; SCL: Short chain length; SDG: Sustainable development goal; sol: Soluble; TN: Total nitrogen; TP: Total phosphorus; VFA: Volatile fatty acid.
\end{abstract}

\section{Acknowledgements}

Not applicable.

\section{Authors' contributions}

HYL, C-KC, J-SC and PLS conceptualised the manuscript. HYL and C-KC were the major contributor in writing, reviewing, editing and visualising the manuscript. KSK, KWC and SRC participated in writing, reviewing and editing the manuscript. JWL was the project funder. JWL, J-SC and PLS were the project administrator. All authors read and approved the final manuscript.

\section{Funding}

The authors would like to acknowledge the financial supports from Yayasan Universiti Teknologi PETRONAS via YUTP-FRG with the cost centre of 015LCO126, the Ministry of Higher Education Malaysia via HICoE-Centre for Biofuel and Biochemical Research with the cost centre of 015MA0-052, the Malaysia Fundamental Research Grant Scheme (FRGS/1/2019/STG05/UNIM/02/2) and the MyPAIR-PHC-Hibiscus Grant (MyPAIR/1/2020/STG05/UNIM/1).

\section{Availability of data and materials}

Not applicable.

\section{Declarations}

Ethics approval and consent to participate

Not applicable.

\section{Consent for publication}

Not applicable.

\section{Competing interests}

The authors declare that they have no competing interests.

\section{Author details}

${ }^{1}$ Key Laboratory of Biomass Chemical Engineering of Ministry of Education, College of Chemical and Biological Engineering, Zhejiang University, Hangzhou 310027, China. ${ }^{2}$ Department of Chemical Engineering and Materials Science, Yuan Ze University, No. 135, Yuan-Tung Road, Chungli, Taoyuan 320, Taiwan. ${ }^{3}$ Department of Chemical and Environmental Engineering, Faculty of Science and Engineering, University of Nottingham Malaysia, Jalan Broga, 43500 Semenyih, Selangor Darul Ehsan, Malaysia. ${ }^{4}$ School of Energy and Chemical Engineering, Xiamen University Malaysia, Jalan Sunsuria, Bandar Sunsuria, 43900 Sepang, Selangor Darul Ehsan, Malaysia. ${ }^{5}$ Department of Fundamental and Applied Sciences, HICoE-Centre for Biofuel and Biochemical Research, Institute of Self-Sustainable Building, Universiti Teknologi PETRONAS, 32610 Seri Iskandar, Perak Darul Ridzuan, Malaysia. ${ }^{6}$ Department of Chemical Engineering, National Cheng Kung University, Tainan 701, Taiwan. ${ }^{7}$ Department of Chemical and Materials Engineering, College of Engineering, Tunghai University, Taichung 407, Taiwan. ${ }^{8}$ Research Center for Smart Sustainable Circular Economy, Tunghai University, Taichung 407, Taiwan.

Received: 1 April 2020 Accepted: 27 March 2021

Published online: 07 April 2021

\section{References}

1. Worldometer. World Population Clock: 7.8 Billion People (2020) Worldometer. 2020. https://www.worldometers.info/world-population/. Accessed 10 Aug 2020.

2. Hoornweg D, Bhada-Tata P, Kennedy C. Environment: waste production must peak this century. Nature. 2013;502(7473):615-7.

3. Conserve Energy Future. Top 25 Environmental Concerns. 2020. https:// www.conserve-energy-future.com/top-25-environmental-concerns. php. Accessed 10 Mar 2020

4. United Nations Foundation. 5 Global Issues to Watch in 2020. 2020. https://unfoundation.org/blog/post/5-global-issues-to-watch-in-2020/. Accessed 12 Mar 2020.

5. United Nations. Global Issues Overview. 2020. https://www.un.org/en/ sections/issues-depth/global-issues-overview/. Accessed 12 Mar 2020.

6. United Nations. Climate Change. 2020. https://www.un.org/en/secti ons/issues-depth/climate-change/index.html. Accessed 12 Mar 2020

7. Carus M, Dammer, L. The "Circular Bioeconomy" - concepts, opportunities and limitations. In: Bio-based economy 2018-01. nova-Institut, Hürth (Germany). 2018. https://www.bio-based.eu/nova-papers. Accessed 10 Sept 2019.

8. Venkata Mohan S, Nikhil GN, Chiranjeevi P, Nagendranatha Reddy C, Rohit MV, Kumar AN, Sarkar O. Waste biorefinery models towards sustainable circular bioeconomy: critical review and future perspectives. Bioresour Technol. 2016;215:2-12.

9. Venkata Mohan S, Modestra JA, Amulya K, Butti SK, Velvizhi G. A circular bioeconomy with biobased products from $\mathrm{CO}_{2}$ sequestration. Trends Biotechnol. 2016;34(6):506-19.

10. IEA Bioenergy. IEA Bioenergy Task 42 Biorefinery. 2019. https://www.ieabioenergy.task42-biorefineries.com/en/ieabiorefinery/Activities.htm. Accessed 27 Sept 2019.

11. Dahiya S, Kumar AN, Shanthi Sravan J, Chatterjee S, Sarkar O, Mohan SV. Food waste biorefinery: sustainable strategy for circular bioeconomy. Bioresour Technol. 2018:248:2-12.

12. Mishra S, Roy M, Mohanty K. Microalgal bioenergy production under zero-waste biorefinery approach: recent advances and future perspectives. Bioresour Technol. 2019;292:122008.

13. Li S-Y, Ng IS, Chen PT, Chiang C-J, Chao Y-P. Biorefining of protein waste for production of sustainable fuels and chemicals. Biotechnol Biofuels. 2018;11(1):256.

14. Zeng X, Guo X, Su G, Danquah MK, Zhang S, Lu Y, Sun Y, Lin L. Bioprocess considerations for microalgal-based wastewater treatment and biomass production. Renew Sustain Energy Rev. 2015;42:1385-92.

15. Ferreira JA, Mahboubi A, Lennartsson PR, Taherzadeh MJ. Waste biorefineries using filamentous ascomycetes fungi: present status and future prospects. Bioresour Technol. 2016;215:334-45. 
16. Parajuli R, Dalgaard T, Jørgensen U, Adamsen APS, Knudsen MT, Birkved M, Gylling M, Schjørring JK. Biorefining in the prevailing energy and materials crisis: a review of sustainable pathways for biorefinery value chains and sustainability assessment methodologies. Renew Sustain Energy Rev. 2015;43:244-63.

17. Bhaskar T, Pandey A, Mohan SV, Lee D-J, Khanal SK. Waste biorefinery: potential and perspectives. The Netherlands: Elsevier; 2018.

18. NASA. Mitigation and adaptation | solutions_-responding to climate change. 2019. https://climate.nasa.gov/solutions/adaptation-mitig ation/. Accessed 27 Sept 2019.

19. Jørgensen S, Pedersen LJT. The circular rather than the linear economy. In: RESTART sustainable business model innovation. Cham: Springer International Publishing; 2018. p. 103-20.

20. Ferreira JA, Agnihotri S, Taherzadeh MJ. Chapter 3-Waste biorefinery. In: Taherzadeh MJ, Bolton K, Wong J, Pandey A, editors. Sustainable resource recovery and zero waste approaches. The Netherlands: Elsevier; 2019. p. 35-52.

21. Venkata Mohan S, Butti SK, Amulya K, Dahiya S, Modestra JA. Waste biorefinery: a new paradigm for a sustainable bioelectro economy. Trends Biotechnol. 2016;34(11):852-5.

22. Zhou M, Yan B, Wong JWC, Zhang Y. Enhanced volatile fatty acids production from anaerobic fermentation of food waste: a mini-review focusing on acidogenic metabolic pathways. Bioresour Technol. 2018:248:68-78.

23. Leiva-Candia DE, Pinzi S, Redel-Macías MD, Koutinas A, Webb C, Dorado MP. The potential for agro-industrial waste utilization using oleaginous yeast for the production of biodiesel. Fuel. 2014;123:33-42.

24. Anjum M, Qadeer S, Khalid A. Anaerobic co-digestion of catering and agro-industrial waste: a step forward toward waste biorefinery. Front Energy Res. 2018;6(116)

25. Liguori R, Faraco V. Biological processes for advancing lignocellulosic waste biorefinery by advocating circular economy. Bioresour Technol. 2016;215:13-20.

26. Cheng WN, Yi H, Yu C-f, Wong HF, Wang G, Kwon EE, Tsang YF. Biorefining waste sludge from water and sewage treatment plants into ecoconstruction material. Front Energy Res. 2019;7(22).

27. Ferreira JA, Brancoli P, Agnihotri S, Bolton K, Taherzadeh MJ. A review of integration strategies of lignocelluloses and other wastes in 1st generation bioethanol processes. Process Biochem. 2018;75:173-86.

28. Devadas WV, Khoo KS, Chia WY, Chew KW, Munawaroh HSH, Lam M-K, Lim J-W, Ho Y-C, Lee KT, Show PL. Algae biopolymer towards sustainable circular economy. Bioresour Technol. 2021;325:124702.

29. Du C, Sabirova J, Soetaert W, Ki C, Lin S. Polyhydroxyalkanoates production from low-cost sustainable raw materials. Curr Chem Biol. 2012;6(1):14-25

30. Ghysels S, Mozumder MSI, De Wever H, Volcke EIP, Garcia-Gonzalez L. Targeted poly(3-hydroxybutyrate-co-3-hydroxyvalerate) bioplastic production from carbon dioxide. Bioresour Technol. 2018;249:858-68.

31. Castilho LR, Mitchell DA, Freire DMG. Production of polyhydroxyalkanoates (PHAs) from waste materials and by-products by submerged and solid-state fermentation. Bioresour Technol. 2009;100(23):5996-6009.

32. Możejko-Ciesielska J, Kiewisz R. Bacterial polyhydroxyalkanoates: still fabulous? Microbiol Res. 2016;192:271-82.

33. Albuquerque PBS, Malafaia CB. Perspectives on the production, structural characteristics and potential applications of bioplastics derived from polyhydroxyalkanoates. Int J Biol Macromol. 2018;107:615-25.

34. Pakalapati H, Chang C-K, Show PL, Arumugasamy SK, Lan JC-W. Development of polyhydroxyalkanoates production from waste feedstocks and applications. J Biosci Bioeng. 2018;126(3):282-92.

35. Koller M, Bona R, Braunegg G, Hermann C, Horvat P, Kroutil M, Martinz J, Neto J, Pereira L, Varila P. Production of polyhydroxyalkanoates from agricultural waste and surplus materials. Biomacromol. 2005;6(2):561-5.

36. Fernández D, Rodríguez E, Bassas M, Viñas M, Solanas AM, Llorens J, Marqués AM, Manresa A. Agro-industrial oily wastes as substrates for PHA production by the new strain Pseudomonas aeruginosa $\mathrm{NCIB}$ 40045: effect of culture conditions. Biochem Eng J. 2005;26(2):159-67.

37. Yu J. Production of PHA from starchy wastewater via organic acids. J Biotechnol. 2001;86(2):105-12

38. RamKumar Pandian S, Deepak V, Kalishwaralal K, Rameshkumar N, Jeyaraj M, Gurunathan S. Optimization and fed-batch production of
PHB utilizing dairy waste and sea water as nutrient sources by Bacillus megaterium SRKP-3. Bioresour Technol. 2010;101(2):705-11.

39. Venkateswar Reddy M, Venkata MS. Influence of aerobic and anoxic microenvironments on polyhydroxyalkanoates (PHA) production from food waste and acidogenic effluents using aerobic consortia. Bioresour Technol. 2012;103(1):313-21.

40. Cavalheiro JMBT, de Almeida MCMD, Grandfils C, da Fonseca MMR. Poly(3-hydroxybutyrate) production by Cupriavidus necator using waste glycerol. Process Biochem. 2009;44(5):509-15.

41. Pernicova I, Kucera D, Nebesarova J, Kalina M, Novackova I, Koller M, Obruca S. Production of polyhydroxyalkanoates on waste frying oil employing selected Halomonas strains. Bioresour Technol. 2019;292:122028.

42. Colombo B, Villegas Calvo M, Pepè Sciarria T, Scaglia B, Savio Kizito S, D'Imporzano G, Adani F. Biohydrogen and polyhydroxyalkanoates (PHA) as products of a two-steps bioprocess from deproteinized dairy wastes. Waste Manag. 2019;95:22-31.

43. Al-Battashi H, Annamalai N, Al-Kindi S, Nair AS, Al-Bahry S, Verma JP, Sivakumar N. Production of bioplastic (poly-3-hydroxybutyrate) using waste paper as a feedstock: optimization of enzymatic hydrolysis and fermentation employing Burkholderia sacchari. J Clean Prod. 2019;214:236-47.

44. Ghosh S, Gnaim R, Greiserman S, Fadeev L, Gozin M, Golberg A. Macroalgal biomass subcritical hydrolysates for the production of polyhydroxyalkanoate (PHA) by Haloferax mediterranei. Bioresour Technol. 2019;271:166-73.

45. Tsouko E, Kourmentza C, Ladakis D, Kopsahelis N, Mandala I, Papanikolaou S, Paloukis F, Alves V, Koutinas A. Bacterial cellulose production from industrial waste and by-product streams. Int J Mol Sci. 2015;16(7):14832-49.

46. Torres F, Arroyo J, Troncoso O. Bacterial cellulose nanocomposites: an all-nano type of material. Mater Sci Eng C. 2019;98:1277-93.

47. Hussain Z, Sajjad W, Khan T, Wahid F. Production of bacterial cellulose from industrial wastes: a review. Cellulose. 2019;26(5):2895-911.

48. Cavka A, Guo X, Tang S-J, Winestrand S, Jönsson L, Hong F. Production of bacterial cellulose and enzyme from waste fiber sludge. Biotechnol Biofuels. 2013;6(1):25.

49. Lin D, Lopez-Sanchez P, Li R, Li Z. Production of bacterial cellulose by Gluconacetobacter hansenii CGMCC 3917 using only waste beer yeast as nutrient source. Bioresour Technol. 2014;151:113-9.

50. Khattak WA, Khan T, UI-Islam M, Wahid F, Park JK. Production, characterization and physico-mechanical properties of bacterial cellulose from industrial wastes. J Polym Environ. 2015;23(1):45-53.

51. Li Z, Wang L, Hua J, Jia S, Zhang J, Liu H. Production of nano bacterial cellulose from waste water of candied jujube-processing industry using Acetobacter xylinum. Carbohydr Polym. 2015;120:115-9.

52. Costa AFS, Almeida FCG, Vinhas GM, Sarubbo LA. Production of bacterial cellulose by Gluconacetobacter hansenii using corn steep liquor as nutrient sources. Front Microbiol. 2017;8:2027.

53. Dubey S, Singh J, Singh RP. Biotransformation of sweet lime pulp waste into high-quality nanocellulose with an excellent productivity using Komagataeibacter europaeus SGP37 under static intermittent fed-batch cultivation. Bioresour Technol. 2018;247:73-80.

54. Yong JJJY, Chew KW, Khoo KS, Show PL, Chang J-S. Prospects and development of algal-bacterial biotechnology in environmental management and protection. Biotechnol Adv. 2021;47:107684.

55. Amaro HM, Guedes AC, Malcata FX. Advances and perspectives in using microalgae to produce biodiesel. Appl Energy. 2011;88(10):3402-10.

56. Fontanille P, Kumar V, Christophe G, Nouaille R, Larroche C. Bioconversion of volatile fatty acids into lipids by the oleaginous yeast Yarrowia lipolytica. Bioresour Technol. 2012;114:443-9.

57. Masri MA, Garbe D, Mehlmer N, Brück TB. A sustainable, high-performance process for the economic production of waste-free microbial oils that can replace plant-based equivalents. Energy Environ Sci. 2019;12(9):2717-32.

58. Jiang L, Sun J, Nie C, Li Y, Jenkins J, Pei H. Filamentous cyanobacteria triples oil production in seawater-based medium supplemented with industrial waste: monosodium glutamate residue. Biotechnol Biofuels. 2019;12(1):53

59. Kumar R, Biswas K, Singh PK, Singh PK, Elumalai S, Shukla P, Pabbi S. Lipid production and molecular dynamics simulation for regulation of 
accD gene in cyanobacteria under different $\mathrm{N}$ and $\mathrm{P}$ regimes. Biotechnol Biofuels. 2017;10(1):94.

60. Leong W-H, Lim J-W, Lam M-K, Uemura Y, Ho Y-C. Third generation biofuels: a nutritional perspective in enhancing microbial lipid production. Renew Sustain Energy Rev. 2018;91:950-61.

61. Chen J, Zhang X, Tyagi RD. Impact of nitrogen on the industrial feasibility of biodiesel production from lipid accumulated in oleaginous yeast with wastewater sludge and crude glycerol. Energy. 2021;217:119343.

62. Gong Z, Shen H, Zhou W, Wang Y, Yang X, Zhao ZK. Efficient conversion of acetate into lipids by the oleaginous yeast Cryptococcus curvatus. Biotechnol Biofuels. 2015;8(1):189.

63. Huang X-F, Liu J-N, Lu L-J, Peng K-M, Yang G-X, Liu J. Culture strategies for lipid production using acetic acid as sole carbon source by Rhodosporidium toruloides. Bioresour Technol. 2016;206:141-9.

64. Xavier MCA, Coradini ALV, Deckmann AC, Franco TT. Lipid production from hemicellulose hydrolysate and acetic acid by Lipomyces starkeyi and the ability of yeast to metabolize inhibitors. Biochem Eng J. 2017;118:11-9.

65. Lopes M, Gomes AS, Silva CM, Belo I. Microbial lipids and added value metabolites production by Yarrowia lipolytica from pork lard. J Biotechnol. 2018;265:76-85.

66. Khoo KS, Chew KW, Yew GY, Leong WH, Chai YH, Show PL, Chen W-H. Recent advances in downstream processing of microalgae lipid recovery for biofuel production. Bioresour Technol. 2020;304:122996.

67. Tang DYY, Khoo KS, Chew KW, Tao Y, Ho S-H, Show PL. Potential utilization of bioproducts from microalgae for the quality enhancement of natural products. Bioresour Technol. 2020;304:122997.

68. Chew KW, Yap JY, Show PL, Suan NH, Juan JC, Ling TC, Lee D-J, Chang J-S. Microalgae biorefinery: high value products perspectives. Bioresour Technol. 2017;229:53-62.

69. Chia SR, Ong HC, Chew KW, Show PL, Phang S-M, Ling TC, Nagarajan D, Lee D-J, Chang J-S. Sustainable approaches for algae utilisation in bioenergy production. Renew Energy. 2018;129:838-52.

70. Hong W-K, Yu A, Heo S-Y, Oh B-R, Kim CH, Sohn J-H, Yang J-W, Kondo A, Seo J-W. Production of lipids containing high levels of docosahexaenoic acid from empty palm fruit bunches by Aurantiochytrium sp. KRS101. Bioprocess Biosyst Eng. 2013;36(7):959-63.

71. Chiranjeevi P,Venkata MS. Diverse acidogenic effluents as feedstock for microalgae cultivation: dual phase metabolic transition on biomass growth and lipid synthesis. Bioresour Technol. 2017;242:191-6.

72. Chang H, Quan X, Zhong N, Zhang Z, Lu C, Li G, Cheng Z, Yang L. Highefficiency nutrients reclamation from landfill leachate by microalgae Chlorella vulgaris in membrane photobioreactor for bio-lipid production. Bioresour Technol. 2018;266:374-81.

73. Nguyen TDP, Nguyen DH, Lim JW, Chang C-K, Leong HY, Tran TNT, Vu TBH, Nguyen TTC, Show PL. Investigation of the relationship between bacteria growth and lipid production cultivating of microalgae Chlorella vulgaris in seafood wastewater. Energies. 2019;12(12):2282.

74. Cheah WY, Show PL, Juan JC, Chang J-S, Ling TC. Microalgae cultivation in palm oil mill effluent (POME) for lipid production and pollutants removal. Energy Convers Manage. 2018;174:430-8.

75. Kumsiri B, Pekkoh J, Pathom-aree W, Lumyong S, Pumas C. Synergistic effect of co-culture of microalga and actinomycete in diluted chicken manure digestate for lipid production. Algal Res. 2018;33:239-47.

76. Leong HY, Su C-A, Lee B-S, Lan JC-W, Law CL, Chang J-S, Show PL. Development of Aurantiochytrium limacinum SR21 cultivation using salt-rich waste feedstock for docosahexaenoic acid production and application of natural colourant in food product. Bioresour Technol. 2019;271:30-6.

77. León-Vaz A, León R, Díaz-Santos E, Vigara J, Raposo S. Using agro-industrial wastes for mixotrophic growth and lipids production by the green microalga Chlorella sorokiniana. New Biotechnol. 2019;51:31-8.

78. Ren H-Y, Kong F, Zhao L, Ren N-Q, Ma J, Nan J, Liu B-F. Enhanced coproduction of biohydrogen and algal lipids from agricultural biomass residues in long-term operation. Bioresour Technol. 2019;289:121774.

79. Ren H-Y, Kong F, Cui Z, Zhao L, Ma J, Ren N-Q, Liu B-F. Cogeneration of hydrogen and lipid from stimulated food waste in an integrated dark fermentative and microalgal bioreactor. Bioresour Technol. 2019;287:121468.
80. Christenson L, Sims R. Production and harvesting of microalgae for wastewater treatment, biofuels, and bioproducts. Biotechnol Adv. 2011;29(6):686-702.

81. Park JBK, Craggs RJ, Shilton AN. Wastewater treatment high rate algal ponds for biofuel production. Bioresour Technol. 2011;102(1):35-42.

82. Madakka M, Jayaraju N, Rajesh N, Subhosh Chandra MRG. Chapter 20 Development in the treatment of municipal and industrial wastewater by microorganism. In: Buddolla V, editor. Recent developments in applied microbiology and biochemistry. USA: Academic Press; 2019. p. 263-73.

83. Sarris D, Giannakis M, Philippoussis A, Komaitis M, Koutinas AA, Papanikolaou S. Conversions of olive mill wastewater-based media by Saccharomyces cerevisiae through sterile and non-sterile bioprocesses. $\rfloor$ Chem Technol Biotechnol. 2013;88(5):958-69.

84. Muniraj IK, Xiao L, Hu Z, Zhan X, Shi J. Microbial lipid production from potato processing wastewater using oleaginous filamentous fungi Aspergillus oryzae. Water Res. 2013;47(10):3477-83.

85. Anastasi A, Spina F, Prigione V, Tigini V, Giansanti P, Varese GC. Scale-up of a bioprocess for textile wastewater treatment using Bjerkandera adusta. Bioresour Technol. 2010;101(9):3067-75.

86. Makut BB, Das D, Goswami G. Production of microbial biomass feedstock via co-cultivation of microalgae-bacteria consortium coupled with effective wastewater treatment: a sustainable approach. Algal Res. 2019;37:228-39.

87. Zheng H, Liu M, Lu Q, Wu X, Ma Y, Cheng Y, Addy M, Liu Y, Ruan R. Balancing carbon/nitrogen ratio to improve nutrients removal and algal biomass production in piggery and brewery wastewaters. Bioresour Technol. 2018;249:479-86.

88. Mujtaba G, Rizwan M, Lee K. Removal of nutrients and COD from wastewater using symbiotic co-culture of bacterium Pseudomonas putida and immobilized microalga Chlorella vulgaris. J Ind Eng Chem. 2017:49:145-51.

89. Zhu S, Qin L, Feng P, Shang C, Wang Z, Yuan Z. Treatment of low C/N ratio wastewater and biomass production using co-culture of Chlorella vulgaris and activated sludge in a batch photobioreactor. Bioresour Technol. 2019;274:313-20.

90. Piligaev AV, Sorokina KN, Shashkov MV, Parmon VN. Screening and comparative metabolic profiling of high lipid content microalgae strains for application in wastewater treatment. Bioresour Technol. 2018:250:538-47.

91. Ren H-Y, Liu B-F, Kong F, Zhao L, Ren N. Hydrogen and lipid production from starch wastewater by co-culture of anaerobic sludge and oleaginous microalgae with simultaneous COD, nitrogen and phosphorus removal. Water Res. 2015;85:404-12.

92. Khouni I, Marrot B, Amar RB. Treatment of reconstituted textile wastewater containing a reactive dye in an aerobic sequencing batch reactor using a novel bacterial consortium. Sep Purif Technol. 2012;87:110-9.

93. Morgan-Sagastume F, Hjort M, Cirne D, Gérardin F, Lacroix S, Gaval G, Karabegovic L, Alexandersson T, Johansson P, Karlsson A, Bengtsson S, Arcos-Hernández MV, Magnusson P, Werker A. Integrated production of polyhydroxyalkanoates (PHAs) with municipal wastewater and sludge treatment at pilot scale. Bioresour Technol. 2015;181:78-89.

94. Ziara RMM, Miller DN, Subbiah J, Dvorak BI. Lactate wastewater dark fermentation: the effect of temperature and initial pH on biohydrogen production and microbial community. Int J Hydrogen Energy. 2019;44(2):661-73.

95. Singh R, Kumar A, Kirrolia A, Kumar R, Yadav N, Bishnoi NR, Lohchab RK. Removal of sulphate, $\mathrm{COD}$ and $\mathrm{Cr}(\mathrm{VI})$ in simulated and real wastewater by sulphate reducing bacteria enrichment in small bioreactor and FTIR study. Bioresour Technol. 2011;102(2):677-82.

96. Delgadillo-Mirquez L, Lopes F, Taidi B, Pareau D. Nitrogen and phosphate removal from wastewater with a mixed microalgae and bacteria culture. Biotechnol Rep. 2016;1 1:18-26.

97. Bengtsson S, Karlsson A, Alexandersson T, Quadri L, Hjort M, Johansson P, Morgan-Sagastume F, Anterrieu S, Arcos-Hernandez M, Karabegovic $L$, Magnusson P, Werker A. A process for polyhydroxyalkanoate (PHA) production from municipal wastewater treatment with biological carbon and nitrogen removal demonstrated at pilot-scale. New Biotechnol. 2017;35:42-53. 
98. Schultz PW. New environmental theories: empathizing with nature: the effects of perspective taking on concern for environmental issues. J Soc Issues. 2000;56(3):391-406.

99. Demirbaş A. Energy and environmental issues relating to greenhouse gas emissions in Turkey. Energy Convers Manage. 2003;44(1):203-13.

100. Falkowski P, Scholes RJ, Boyle E, Canadell J, Canfield D, Elser J, Gruber N, Hibbard K, Högberg P, Linder S, Mackenzie FT, Moore B III, Pedersen T, Rosenthal Y, Seitzinger S, Smetacek V, Steffen W. The global carbon cycle: a test of our knowledge of earth as a system. Science. 2000;290(5490):291-6.

101. Chae Y, An Y-J. Current research trends on plastic pollution and ecological impacts on the soil ecosystem: a review. Environ Pollut. 2018;240:387-95

102. Derraik JGB. The pollution of the marine environment by plastic debris: a review. Mar Pollut Bull. 2002;44(9):842-52.
103. Grady CL Jr, Daigger GT, Love NG, Filipe CD. Biological wastewater treatment. USA: CRC Press; 2011

104. Brennan L, Owende P. Biofuels from microalgae - a review of technologies for production, processing, and extractions of biofuels and co-products. Renew Sustain Energy Rev. 2010;14(2):557-77.

105. Ragauskas AJ, Williams CK, Davison BH, Britovsek G, Cairney J, Eckert CA, Frederick WJ, Hallett JP, Leak DJ, Liotta CL, Mielenz JR, Murphy R, Templer R, Tschaplinski T. The path forward for biofuels and biomaterials. Science. 2006;311(5760):484-9.

\section{Publisher's Note}

Springer Nature remains neutral with regard to jurisdictional claims in published maps and institutional affiliations.
Ready to submit your research? Choose BMC and benefit from:

- fast, convenient online submission

- thorough peer review by experienced researchers in your field

- rapid publication on acceptance

- support for research data, including large and complex data types

- gold Open Access which fosters wider collaboration and increased citations

- maximum visibility for your research: over $100 \mathrm{M}$ website views per year

At BMC, research is always in progress.

Learn more biomedcentral.com/submissions 